\title{
Cooperative Milk Farms of Germany: Position and Perspectives under the Conditions of Globalization
}

\author{
Igor Tonkoshkurov, Khakassia State University named after Nikolaj Katanov, \\ Russia
}

\begin{abstract}
The article considers the analysis of cooperative milk farms in German. Special attention is paid to influence of globalization on development of cooperative farms in the milk production. Cooperatives are going to become one of the most attractive forms of businesses. In German decreased the number of cooperatives during last decade. However their structure is getting more complicated and improved.
\end{abstract}

JEL code: Q13

\section{Introduction}

Traditionally, Germany has a considerable part of the world milk market. During the last decade (1999-2009) some changes took place in the processes around milk production, primarily structural changes. The main goal of this article is to research the current condition of cooperatives in German milk production and in so doing determine the major perspective their development.

Since the 1980s, structural issues began to develop in the German milk production process and throughout the EU. Milk production experiences pressure both from demand and supply. The supply in European Union includes about $15 \%$ of the total volume [1]. Arrangements of agrarian reform have led to a reduction of government assistance on the demand side. These occurrences complicate the position of producers of milk industry, and they can be compensated for by economic efficiency upgrading of production.

\section{Cooperative milk farms in Germany: Present situation}

Only cooperative enterprises have more opportunities in such situations because cooperatives have opportunity to reduce some costs rapidly on account of combined purchases of raw material and fodder, seeds, appointments, equipment, etc. Therefore the part of milk, which is processed by cooperative farms in Germany, increased $60 \%$ in recent years [2]. At that time the number of cooperative milk enterprises processing milk was reduced by $50 \%$. Cooperatives take part in more profound specialization and cooperation of production. Such enterprise structures combined with the practice of varied forms of creation, process and sale of production is more economical. The three global factors for the consolidation of the milk industry are as follows:

- first, cost reduction by combined purchases of raw material and fodder, seeds, appointments, equipment;

- $\quad$ second, development and appearance of new markets; big producers unite different national markets under one „roof" of their enterprise, which allows the optimization of research-and-development spending and business expansion schemes as well as the reduction of marketing and advertising costs. Such big corporations have a significant part of the global market, a considerable client base, and excellent reputations; therefore, it is difficult for separate enterprises to enter new markets without taking part in the process of cooperation;

- and, third, the necessity of continual innovation. The strongest competition in the global markets require the German producers of milk products to continually refine 
the production process, as well as the production of new kinds of milk products. This requires big investments that separate small and mid-sized enterprises cannot put into practice. Only big producers have an opportunity to invest in innovative projects and productive-technological research initiatives. For that matter cooperative unions render considerable assistance to their members by supporting scientific-practical symposiums and conferences, workshops, flows of technological knowledge, and so on.

Data about the cooperative German farms are showed in table 1. The federal state of Bavaria (the regional union is located in Munich) has remained the milk production center for many years. However it is of note that the role of regional unions in the federal states of NordrheinWestfalen (Munster) and Niedersachsen (Hannover) increased greatly during the last decade. Institut für Genossenschaftswesen im Centrum für Angewandte Wirtschaftsforschung Westfälische Wilhelms-Universität (The Institute of Cooperation at the University of Münster) provides the greatest contribution in the development of cooperation in agriculture and the milk industry. This Institute manages many production projects and collaborates actively with regional enterprises and associations.

\begin{tabular}{|l|c|c|c|c|c|}
\hline $\begin{array}{c}\text { Regional } \\
\text { Union }\end{array}$ & $\begin{array}{c}\text { Milk } \\
\text { working } \\
\text { enterprises }\end{array}$ & $\begin{array}{c}\text { Delivery } \\
\text { cooperatives of } \\
\text { milk products }\end{array}$ & $\begin{array}{c}\text { Other } \\
\text { Products } \\
\text { and Costs }\end{array}$ & Total & $\begin{array}{c}\text { Return } \\
\text { (million } \\
\text { euro) }\end{array}$ \\
\hline Hannover & 20 & 26 & 10 & 56 & 3.664 \\
\hline Oldenburg & 2 & 4 & 3 & 9 & 461 \\
\hline Munster & 3 & 4 & & 7 & 3.298 \\
\hline Karlsruhe & 1 & 2 & 4 & 7 & 200 \\
\hline Stuttgart & 6 & 22 & & 28 & 851 \\
\hline Munich & 28 & 147 & & 175 & 2.286 \\
\hline Dresden & 2 & 6 & & 8 & - \\
\hline Total: & 62 & 211 & 17 & 290 & 10.760 \\
\hline
\end{tabular}

Table 1 The quantity of cooperative milk enterprises and their return in year 2008, by region [3]

Five enterprises compose over $70 \%$ of the German cooperative dairy market (table 2 ). The biggest corporation is Bremen's «Nordmilch», which has more than one-quarter of the entire return.

\begin{tabular}{|l|c|}
\hline \multicolumn{1}{|c|}{ Kind of enterprise-member of cooperation } & Return (million euro) \\
\hline Milk process enterprises & 10.031 \\
\hline including: & 2.522 \\
\hline Nordmilch AG, Bremen & 2.200 \\
\hline Humana Milchunion eG, Eversvinkel & 1.240 \\
\hline Hochwald Nahrungsmittel GmbH, Talfang & 1.000 \\
\hline Bayernland eG, Nurnberg & 619 \\
\hline Milchunion Hocheifel eG, Pronsfeld & 729 \\
\hline Milk production delivery cooperatives & 10.760 \\
\hline Total: & \\
\hline
\end{tabular}

Table 2 Return of cooperative milk farms by enterprise for 2008 [4]

During 1999-2008, the number of dairy farmers reduced significantly - over 39\% - through processes of conglomeration. This reduction involved both large enterprises and individual dairy farms. In spite of total reduction of milk cows by $12 \%$, the quantity of cows per owner increased by an average of $44 \%$ [5]. This fact witnessed the integration of milk production enterprises and reduction of individual farms and private households. Theoutput of milk and 
milk products was reducedas the number of dairy farms and cattle declined. This was connected with increase in the productivity of the milk market by $19 \%$ from 1999 until 2009. Also it is of note that dairy consumption grew $13 \%$. Furthermore, there was an increase in the output of sour-milk products $(16 \%)$ and cheeses $(25 \%)$. At the same time a reduction took place in the production of condensed milk (by $+25 \%$ ), butter (by - $5 \%$ ) and milk products (by - 31\%) [6]. The biggest rate of increase was in the production of sour-milk products (such as milk drinks, kefir, yogurts, puddings, and so on) in these latter years.

\section{Globalization of the milk production}

The conditions of globalization provide for the continual expansion of sales areas. The main consumers of EU milk productions include the USA, Russia, Algeria, Saudi Arabia, Japan and Switzerland. According to experts' evaluations, by the year 2050 the number of world inhabitants will approach 9 billion people. In connection with the main centers of demographic growth, situated in Africa and Asia, cooperatives have to displace priorities in global sales to these regions. During the period of 2004 until2008, the export of milk production from the EU to Russia, Indonesia and China nearly doubled. As for other countries, their return volumes did not indicate considerable change.

If the global market continues at the same rate as 2009 , it could overcome the deficit of years from 2004 to 2006, when the consumption of milk production exceded their production. During 2001-2008, milk output increased by 944 million ton (13.8\%), and in consumption of 909 million $(13.37 \%)$. Per capita milk consumption increased as well. Underdeveloped regions in Asia, Africa and Latin America remains low with a ration of $0.28 \mathrm{~kg}$ per day per man.

\begin{tabular}{|c|c|c|c|c|c|c|c|c|}
\hline Rate & $\begin{array}{l}200 \\
1\end{array}$ & $\begin{array}{l}200 \\
2\end{array}$ & $\begin{array}{l}200 \\
3\end{array}$ & $\begin{array}{l}200 \\
4\end{array}$ & $\begin{array}{l}200 \\
5\end{array}$ & $\begin{array}{l}200 \\
6\end{array}$ & $\begin{array}{l}200 \\
7\end{array}$ & $\begin{array}{l}200 \\
8\end{array}$ \\
\hline $\begin{array}{l}\text { Production } \\
\text { (million ton) }\end{array}$ & $\begin{array}{l}589 \\
6\end{array}$ & $\begin{array}{l}601 \\
9\end{array}$ & $\begin{array}{l}614 \\
6\end{array}$ & $\begin{array}{l}626 \\
0\end{array}$ & $\begin{array}{l}645 \\
1\end{array}$ & 6612 & $\begin{array}{l}671 \\
0\end{array}$ & $\begin{array}{l}684 \\
0\end{array}$ \\
\hline $\begin{array}{l}\text { consumption } \\
\text { (million ton) }\end{array}$ & $\begin{array}{l}589 \\
1\end{array}$ & $\begin{array}{l}598 \\
2 \\
\end{array}$ & $\begin{array}{l}614 \\
6 \\
\end{array}$ & $\begin{array}{l}627 \\
8 \\
\end{array}$ & $\begin{array}{l}647 \\
8 \\
\end{array}$ & 6631 & $\begin{array}{l}671 \\
0 \\
\end{array}$ & $\begin{array}{l}680 \\
0 \\
\end{array}$ \\
\hline $\begin{array}{l}\text { difference } \\
\text { (million ton) }\end{array}$ & +5 & +37 & 0 & -18 & -27 & -19 & 0 & +40 \\
\hline $\begin{array}{l}\text { per capita } \\
\text { consumption } \\
\text { (kg/year) }\end{array}$ & $\begin{array}{l}95 \\
8\end{array}$ & $\begin{array}{l}96, \\
1\end{array}$ & $\begin{array}{l}97, \\
5\end{array}$ & $\begin{array}{l}98, \\
4\end{array}$ & $\begin{array}{l}100 \\
4\end{array}$ & $\begin{array}{l}101, \\
6\end{array}$ & $\begin{array}{l}101, \\
6\end{array}$ & $\begin{array}{l}101 \\
7\end{array}$ \\
\hline
\end{tabular}

Table 3 Dynamics of production and consumption of milk in the world for years 2001-2008 [7]

At present, the role of government in regulation milk markets is significant (particularly in the determination milk quotas). The basic trend in development of the dairy industry in years to come is the reduction of state influence. Crucial arrangements in this direction include the reduction of trade obstacles (for example, imports) and markets liberalization. The arrangements at the level of the World Trade Organization have a special role in determining this direction.

It is necessary to note, that liberalization, in turn, leads to internationalization of markets around their geographic arrangements. It also increases the dependence of agrarian markets upon other markets (namely, energy and financial markets). Furthermore, we must always consider the instability and inequality of global markets. In this respect the cooperatives have to adapt their structures to market conditions and their various particularities. 


\section{Conclusion.}

Accordingly, only development of cooperative attitudes between enterprises in the process of globalization is a response to changing economic conditions. The cooperation leads to secure enterprises' juridical and economical independence in order to compete with the biggest producers successfully. In this context it is important to note, that the amalgamation of businesses is dependent uponcost-benefit analyses. The amalgamation process needs particular transaction costs, including costs for legal and advisory services, audit, valuation of assets, elaboration of social plans for personnel, and so on. Therefore it is necessary to understand the current situation by careful research of enterprises and trends in their development, all the while considering the process of development of regional and global markets, as well as the state of current world finances.

The main recommendations for further development of milk cooperative farms in Germany under the conditions of globalization are as follows: 1) further perfection of production quality; 2) reduction of production unit quantity; 3) search of new markets; and 4) selection of most effective sales area. The preservation of long-term competitive ability of milk cooperative farms, as well as of meat farms, is connected with considerable investments. Buildup of ownership capital therein acquires the paramount meaning.

\section{References}

- M. Nüssel „Mehr Markt in der Agrarwirtschaft. Herausforerungen und Konsequenzen für die Raiffaisen-Genossenschaften“, Zeitschrift für das gesamte Genossenschaftswesen. - 2006. - Band 56, Heft 2, s. 170.

- M. Nüssel „Mehr Markt in der Agrarwirtschaft. Herausforerungen und Konsequenzen für die Raiffaisen-Genossenschaften“, Zeitschrift für das gesamte Genossenschaftswesen. - 2006. - Band 56, Heft 2, s. 170.

- „Milchmarkt im Umbruch - Situation und Perspektiven aus Sicht der genossenschaftlichen Milchwirtschaft", in Deutscher Raiffeisenverband e. V., Hohenheim, 2009.

- „Milchmarkt im Umbruch - Situation und Perspektiven aus Sicht der genossenschaftlichen Milchwirtschaft", in Deutscher Raiffeisenverband e. V., Hohenheim, 2009.

- $\quad$ Statistische Daten - Wirtschaftliche Bedeutung, http://raiffeisen.de.

- Geschäftsbericht 2008, in Deutscher Genossenschafts- und Raiffeisenverband e.V., Berlin, 2009.

- „Milchmarkt im Umbruch - Situation und Perspektiven aus Sicht der genossenschaftlichen Milchwirtschaft", in Deutscher Raiffeisenverband e. V., Hohenheim, 2009. 